\title{
THE PLACENTAL LOCALISATION OF VIBRIO FETUS
}

\author{
D. B. Lowrie and J. H. Pearce \\ Department of Microbiology, University of Birmingham
}

TISSUE specificity in microbial disease is a common phenomenon (Keppie, 1964; Smith, 1968); it has seldom been explained in biochemical terms, although an understanding of the biochemical basis of localisation of infection could have practical application in, for example, analogue chemotherapy. In brucellosis of ungulates the prolific multiplication of brucellae in placental tissues is correlated with the presence of erythritol, which is a specific growthenhancing nutrient for these organisms (Pearce et al., 1962; Williams, Keppie and Smith, 1962); in guinea-pigs experimentally challenged with brucellae, administration of erythritol analogues significantly reduced infection (Smith et al., 1965). Vibrio fetus also causes placentitis and abortion in cattle and sheep (McFadyean and Stockman, 1913; Smith, 1918; Jensen, Miller and Molello, 1961) and the presence of erythritol or some other nutrient within the ungulate placenta might determine localisation by enhancing the growth of $V$. fetus.

The present paper describes (i) the extent of placental localisation of $V$.fetus in experimental infection of pregnant ewes, (ii) the effect of erythritol on the growth of $V$. fetus in vitro, and (iii) the growth of $V$. fetus in extracts of placental and non-placental ovine tissues.

\section{MATERIALS AND METHODS \\ Experimental infection}

Organisms. Two strains of $V$. fetus were used: $V$. fetus Berryman, a recent isolate from a bovine infection, was given by Dr D. J. MacKinnon, Central Veterinary Laboratory, Weybridge; and $V$. fetus Snape, a recent isolate from an outbreak of ovine abortion, was given by $\mathrm{Mr} \mathrm{T}$. Snape, Allington Farm, Porton. Both strains were classified as V. fetus var. intestinalis on the basis of biochemical tests (Ristic, White and Doty, 1958; Ringen and Frank, 1963) and were subcultured four to five times on laboratory media before being preserved by freeze-drying.

Infection of pregnant ewes. Freeze-dried organisms were grown for 3 days on blood agar containing sodium thioglycollate at $37^{\circ} \mathrm{C}$ in 10 per cent. $\mathrm{CO}_{2}$ in air. The resultant growth was harvested into nutrient broth (see below) and washed twice in broth by centrifugation. The viable count of the final broth suspension was about 5-10 per cent. of the total count (Thoma chamber). Pregnant ewes in the 4th and 5 th $\mathrm{mth}$ of gestation each received intravenously (jugular vein) $4 \mathrm{ml}$ of broth suspension containing $(2-180) \times 10^{9}$ total organisms.

\section{Enumeration of organisms in infected tissues}

Animals were slaughtered at intervals during the development of infection. In each case, the uterus was removed to a dissecting tray, the allantoic membrane was ruptured and the allantoic fluid was collected from the tray before rupture of the amniotic membrane and collection of amniotic fluid. The foetal and maternal cotyledons were separated from one

Received 1 Jan. 1970; accepted 27 Feb. 1970.

J. MED. MICROBIOL.-VOL. 3 (1970) 
another and dissected free from the chorion and uterus respectively; a range of other foetal and maternal tissues was taken.

Signs of infection were recorded as the uterus was dissected; when an animal appeared to be heavily infected, the total wet weight of selected tissues was determined. Convenient amounts (about $5 \mathrm{~g}$ ) were fixed in $10 \mathrm{ml}$ of formol-saline to preserve the staining characteristics of organisms during storage before total bacterial counts were made for each tissue. Each sample, with the added formol-saline, was macerated in an "Omni-mixer" (Ivan Sorvall Inc.) for four periods of $30 \mathrm{~s}$ with 2-min. intervals; after appropriate dilution with saline, a standard loopful was spread uniformly within a circular area $1 \mathrm{~cm}$ in diameter on a slide. The film was dried, heat-fixed and stained with either 1 per cent. carbol fuchsin or neutral red-fast green solution (G. T. Gurr Ltd). The full diameter of the film was traversed twice at $\times 1250$ magnification and the total organisms present in 35-50 fields were counted. Duplicate films were examined and the mean number of organisms per field was calculated. The method was standardised against smears prepared from a suspension of $V$. fetus of known concentration in foetal cotyledon homogenate. In three replicate determinations a mean count of 50 organisms per field was equal to $\left(1.0 \times 10^{9}\right) \pm\left(0.35 \times 10^{9}\right)$ organisms per $\mathrm{ml}$ within 95 per cent. confidence limits.

Tissue samples to be tested for the presence of viable organisms were removed aseptically; blood-thioglycollate agar plates were seeded with loopfuls of material teased from samples and incubated for $4-5$ days at $37^{\circ} \mathrm{C}$ in 10 per cent. $\mathrm{CO}_{2}$ in air.

\section{In-vitro growth studies}

The effect of erythritol (twice-recrystallised from aqueous acetone; G. T. Gurr Ltd) on the growth of $V$. fetus was examined in (i) a nutrient broth, (ii) a chemically defined medium, and (iii) a saline extract of sheep muscle. A comparison of the rates of growth of the test organisms was then made in a range of unsupplemented saline extracts of foetal and maternal ovine tissues.

Nutrient broth. This was the medium used at the Central Veterinary Laboratory for growth of $V$. fetus (Dr D. J. MacKinnon, personal communication); it contained $10 \mathrm{~g}$ peptone (Evans Medical Ltd), $5 \mathrm{~g} \mathrm{Lab}$ Lemco L30 (Oxoid, Ltd), and $5 \mathrm{~g} \mathrm{NaCl}$ in 1 litre of water. The constituents were dissolved by steaming in water that had been double-distilled in all-glass apparatus. The medium was adjusted to $p \mathrm{H} 7 \cdot 8$ with $\mathrm{N}-\mathrm{NaOH}$ and sterilised by membrane filtration $\{0.22 \mu \mathrm{m}$ pore size, detergent-free grade; Millipore (U.K.), Ltd $\}$.

Chemically defined medium. This was the synthetic medium of Fletcher and Plastridge (1963). The amino acids (B.D.H.), niacin (Hopkin and Williams Ltd), sodium acetate and mineral salts (analytical grades) were dissolved in double-distilled water by warming; the medium was adjusted to $p \mathrm{H} 8.0$ with $\mathrm{N}-\mathrm{NaOH}$ and sterilised by membrane filtration.

Saline tissue extracts. These were prepared from tissues collected at slaughter of 3-5-mth pregnant ewes and stored at $-20^{\circ} \mathrm{C}$ for $1-10 \mathrm{mth}$. Samples of $50 \mathrm{~g}$ frozen tissue were thawed with $50 \mathrm{ml}$ of phosphate-buffered saline at $p \mathrm{H} 7.4\left(0.70 \mathrm{~g} \mathrm{KH}_{2} \mathrm{PO}_{4}, 2.13 \mathrm{~g} \mathrm{Na}_{2} \mathrm{HPO}_{4}, 7.50 \mathrm{~g}\right.$ $\mathrm{NaCl}$ in 1 litre of double-distilled water) and macerated at $0^{\circ}-4^{\circ} \mathrm{C}$ for four periods of $30 \mathrm{~s}$ with 2 -min. intervals. The macerate was centrifuged at $18,000 \mathrm{~g}$ for $2 \mathrm{hr}$ at $2^{\circ}-4^{\circ} \mathrm{C}$ and the supernatant was further centrifuged at $150,000 \mathrm{~g}$ for $2 \mathrm{hr}$ at $0^{\circ}-2^{\circ} \mathrm{C}$ after adjustment to $p \mathrm{H} 6.0$ with $\mathrm{N}-\mathrm{NaOH}$. The final supernatant (extract) was sterilised by membrane filtration and stored, $10 \mathrm{ml}$ per $50-\mathrm{ml}$ conical flask, at $-20^{\circ} \mathrm{C}$. The rate of growth of the test organism in an extract was significantly altered if, before the study, the extract was repeatedly frozen and thawed, or stored at $0^{\circ} \mathrm{C}$ for several days or pre-incubated for $12 \mathrm{hr}$. As a routine, extracts were therefore thawed once only, brought to room temperature and seeded with the test strain immediately.

In preliminary experiments, extracts were dialysed, and diffusible and non-diffusible fractions were used to supplement media. A volume of extract was dialysed against an equal volume of double-distilled water with four changes during $60 \mathrm{hr}$ at $4^{\circ} \mathrm{C}$. The diffusible fraction was freeze-dried, dissolved in double-distilled water to a concentration equal to that in the original extract and sterilised by membrane filtration. Precipitate appearing in the 


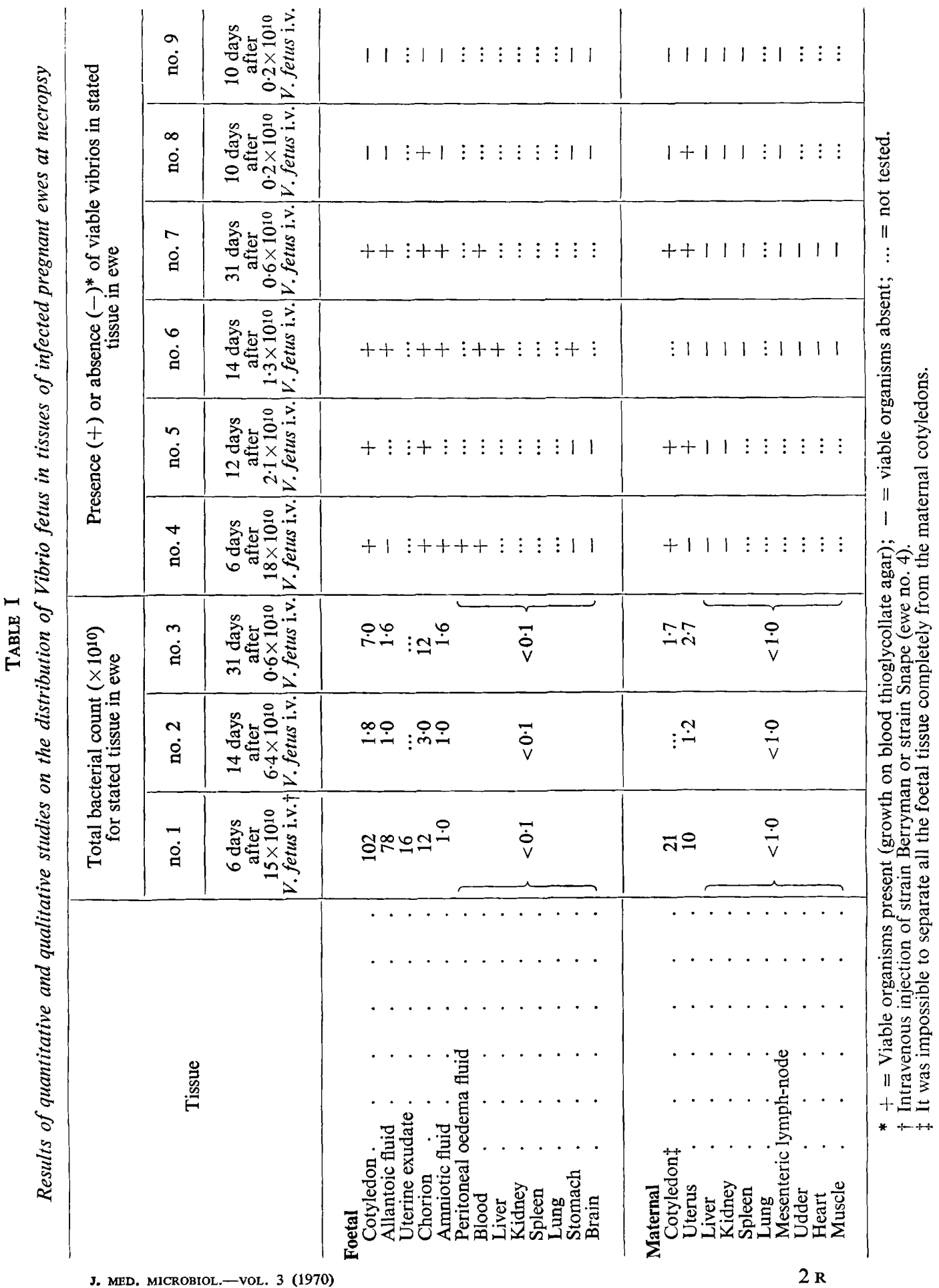


non-diffusible fraction was removed by centrifugation and the supernatant was sterilised by membrane filtration.

Assay of growth. In comparisons of growth rate, inocula were taken from log-phase growth in nutrient broth containing 10 per cent. (v/v) bovine serum (Oxoid, Ltd). The organisms were washed twice by centrifugation in buffered saline and the concentration of the final suspension was adjusted so that $0.1 \mathrm{ml}$ added to $10 \mathrm{ml}$ of medium gave $(1-5) \times 10^{4}$ total organisms per $\mathrm{ml}$. In three determinations the percentage viability of inocula was $82 \pm 21$ (95 per cent. confidence limits). After inoculation of the test strain, 10-ml volumes of medium were incubated statically in cotton-plugged 50-ml conical flasks for $12 \mathrm{hr}$ and samples were withdrawn at 2-hr intervals. Growth was measured by colony count (Miles, Misra and Irwin, 1938; Badger and Pankhurst, 1960) on blood-thioglycollate agar plates incubated for 4 days. The mean number of colonies that developed per drop of a given dilution in nutrient broth was calculated from the number of drops required to provide a total of 200 colonies; results obtained with dilutions that gave drops producing more than 60 colonies were ignored. In five replicate determinations the method was accurate to within \pm 16.7 per cent. ( 95 per cent. confidence limits). Growth was expressed graphically by plotting the $\log _{10}$ numbers of viable organisms per ml against time in hours; exponential growth rate was approximated by the "Least Squares" method and confidence limits were calculated (Mather, 1964); population doubling time in hours was calculated as $\log _{10} 2 \times$ the reciprocal of the growth rate.

\section{RESULTS}

\section{The distribution of $V$. fetus in the tissues of infected pregnant ewes}

In each of nine infected animals examined, viable organisms were confined to the uterine contents (table I). The placenta was pale or necrotic and in some cases there was copious haemorrhagic exudate and chorionic oedema. Large numbers of $V$. fetus were most consistently observed in stained smears from cotyledons; the organism was occasionally detected in very small numbers in the internal organs of the foetus by culture on agar. The degree of pathological change suggested that infection was most advanced in ewe no. 1; the placenta and allantoic fluid contained 84 per cent. of the total of $2.4 \times 10^{12}$ organisms found in this animal.

\section{The effect of erythritol on growth of $V$. fetus}

The doubling time of strain Berryman was determined in a range of media (table II). Supplementation with erythritol at concentrations of $0 \cdot 2-200 \mu \mathrm{g}$ per $\mathrm{ml}$ did not affect the growth rate of the test organism in any of the media.

\section{Growth of $V$. fetus in ovine tissue extracts}

Evidence for the existence of a growth stimulant for $V$. fetus in placental tissues was sought by comparison of growth rates of the organism in different tissue extracts (fig. 1). In all experiments with strain Berryman (table III), the doubling time of the organism grown in foetal cotyledon extract was significantly less than that observed when it was grown in extracts of other tissues with the exception of liver and often kidney. Doubling time was not appreciably affected by two- or three-fold dilution of extracts before inoculation of the test strain. Similar results were obtained with the Snape strain of $V$. fetus.

Preliminary experiments showed that at least part of the material responsible 
for the enhanced growth rate of the test strains in foetal cotyledon extract was diffusible. Fig. 2 shows the results of a typical experiment in which the growth

TABLE II

Growth rates of Vibrio fetus in basal media used for erythritol tests

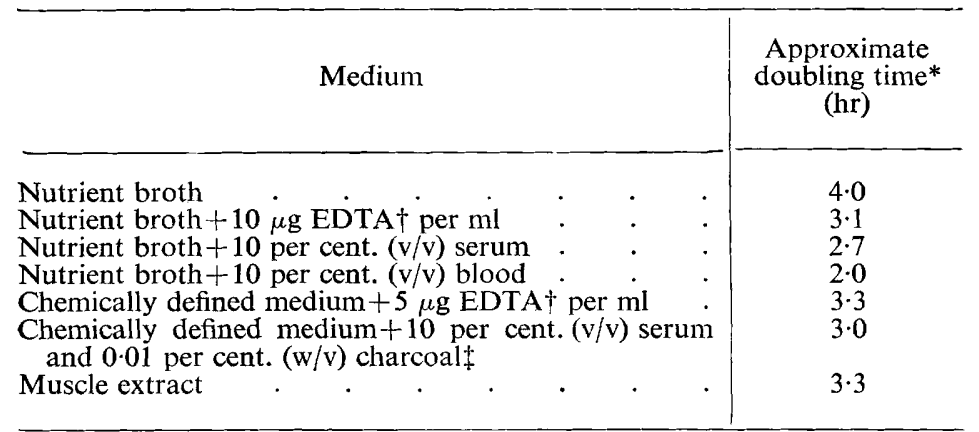

* Doubling times varied in replicate experiments; values most frequently observed are given.

+ Ethylenediamine tetra-acetic acid disodium salt (BDH Ltd).

¥ Bacteriological charcoal (Oxoid, Ltd) purified by heat and acid treatment (Meynell and Meynell, 1965).

TABLE III

Growth rates of Vibrio fetus in extracts of foetal and maternal ovine tissues

\begin{tabular}{|c|c|c|c|c|c|c|}
\hline \multirow{2}{*}{ Tissue extracted } & \multicolumn{6}{|c|}{$\begin{array}{c}\text { Doubling time (hr; } \pm 95 \text { per cent. fiducial limit)* of test organism } \\
\text { grown in extract of stated tissue from ewe }\end{array}$} \\
\hline & no. 10 & no. 11 & no. 12 & no. 13 & no. 14 & no. 15 \\
\hline $\begin{array}{l}\text { Foetal } \\
\text { Cotyledon } \\
\text { Allantoic fluid } \\
\text { Amniotic fluid } \\
\text { Chorion }\end{array}$ & $\begin{array}{c}2 \cdot 0_{ \pm} 0 \cdot 2 \\
0 \\
0 \\
\cdots\end{array}$ & $\begin{array}{c}2 \cdot 4 \pm 0 \cdot 4 \\
0 \\
0 \\
\quad \cdots\end{array}$ & $\begin{array}{c}2 \cdot 3 \pm 0 \cdot 3 \\
3 \cdot 4 \pm 0 \cdot 1 \\
\ldots \\
\ldots\end{array}$ & $\begin{array}{c}1 \cdot 7 \pm 0 \cdot 2 \\
\ldots \\
\ldots \\
2 \cdot 1 \pm 0 \cdot 5\end{array}$ & $\begin{array}{c}1 \cdot 7 \pm 0 \cdot 1 \\
\ldots \\
\ldots \\
\ldots\end{array}$ & $\begin{array}{c}2 \cdot 1 \pm 0 \cdot 4 \\
\ldots \\
\ldots \\
\cdots\end{array}$ \\
\hline $\begin{array}{l}\text { Maternal } \\
\text { Liver } . \\
\text { Kidney } \\
\text { Spleen }:\end{array}$ : $:$ & $\begin{array}{c}1 \cdot 8 \pm 0 \cdot 2 \\
3 \cdot 2 \pm 0 \cdot 3 \\
2 \cdot 9 \pm 0 \cdot 6 \\
4 \cdot 3 \pm 0.5 \\
\ldots \\
\ldots \\
\ldots \\
\ldots\end{array}$ & $\begin{array}{c}1 \cdot 6 \pm 0 \cdot 3 \\
2 \cdot 0 \pm 0.5 \\
3 \cdot 2 \pm 0.4 \\
4 \cdot 0 \pm 1 \cdot 0 \\
\ldots \\
\ldots \\
\ldots \\
\ldots\end{array}$ & $\begin{array}{c}1 \cdot 7 \pm 0 \cdot 3 \\
3 \cdot 2 \pm 0 \cdot 2 \\
3 \cdot 3 \pm 0 \cdot 6 \\
5 \cdot 7 \pm 2 \cdot 1 \\
\ldots \\
\ldots \\
\ldots \\
\ldots\end{array}$ & $\begin{array}{c}1 \cdot 8 \pm 0 \cdot 8 \\
\ldots \\
\ldots \\
2 \cdot 5 \pm 0 \cdot 4 \\
2 \cdot 5 \pm 0.6 \\
0 \\
0\end{array}$ & $\begin{array}{c}1.9 \pm 0.7 \\
\ldots \\
\ldots \\
2 \cdot 3 \pm 0.3 \\
2 \cdot 8 \pm 0.3 \\
0 \\
0\end{array}$ & $\begin{array}{c}1 \cdot 8 \pm 0 \cdot 4 \\
\ldots \\
\ldots \\
5 \cdot 5 \pm 0 \cdot 4 \\
\ldots \\
\ldots \\
\ldots \\
\ldots\end{array}$ \\
\hline
\end{tabular}

rates of standard inocula of $V$. fetus were determined in mixtures of muscle extract with foetal cotyledon extract or one or other of its dialysis fractions. Similar results were obtained in experiments with mixtures of liver extract or 
its dialysis fractions in muscle extract. Although the diffusible fractions of liver and foetal cotyledon extracts enhanced growth in muscle extract, at a

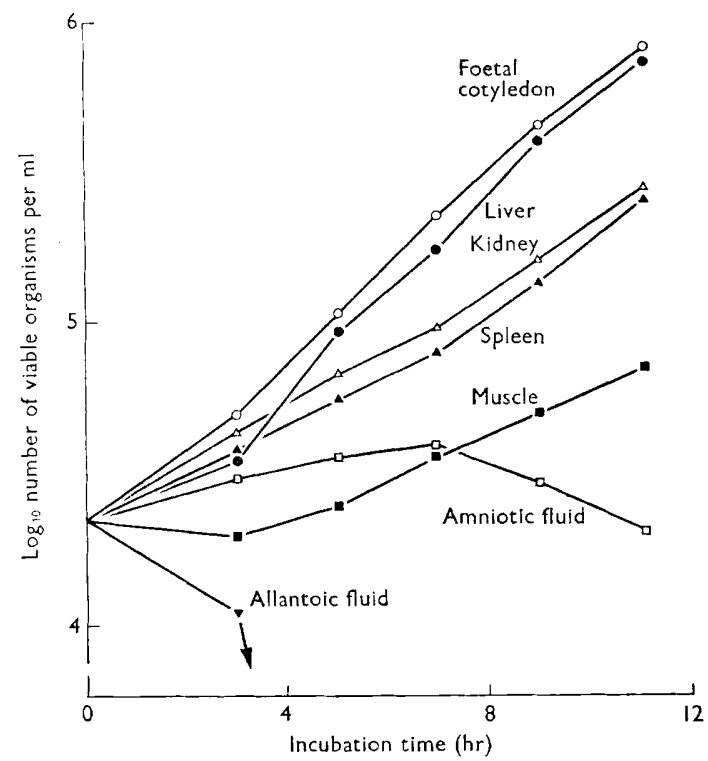

Fig. 1.-Growth rates of Vibrio fetus in extracts of various tissues from ewe no. 10 (see table III).

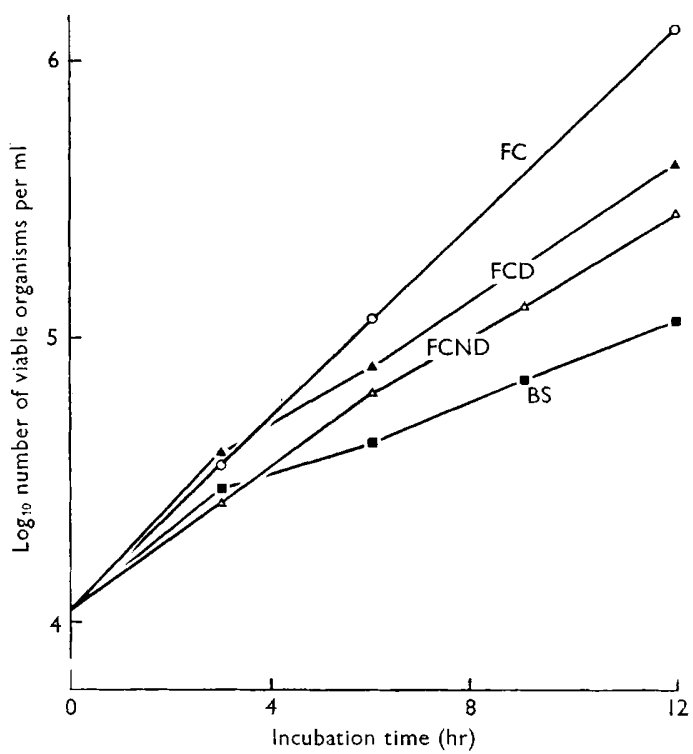

FIG. 2.-Growth in muscle extract supplemented 50 per cent. (v/v) with whole foetal cotyledon extract $(\mathrm{O}-\mathrm{O} \mathrm{FC})$, diffusible $(\triangle-\Lambda \mathrm{FCD})$ or non-diffusible $(\triangle \longrightarrow \triangle \mathrm{FCND})$ dialysis fractions of $\mathrm{FC}$, or buffered saline $(\square \mathrm{BS})$.

two-fold concentration they were markedly toxic; in nutrient broth such fractions were inhibitory, even when they were diluted ten-fold. 


\section{DisCUSSION}

The gross and histopathological changes seen in this study accord with the observations of Jensen et al. (1961) on both natural and experimental ovine vibriosis. Examination of every infected ewe in the present series revealed that there was marked placental localisation of Vibrio fetus; this is convincingly demonstrated in the results obtained with the three animals in which infection was sufficiently advanced to allow accurate determinations of the total numbers of organisms present. In the most heavily infected animal, growth of the test strain was most marked in the foetal cotyledons (cf. Brucella abortus infection of the bovine placenta, Smith et al., 1961). In the less heavily infected animals in the present study, vibrios were found in largest number in the chorion. However, organisms associated with the chorion, uterine wall and uterine exudate could have spread from the foetal cotyledons. Jensen et al. have shown that placental infection is initiated within the hilar zone of the placental union.

Concentrations of erythritol that were stimulatory for growth of Br.abortus (Anderson and Smith, 1965) were without effect on growth of $V$. fetus; neither stimulation nor inhibition of growth was observed, although small inocula giving initial total cell counts of the order of $(1-5) \times 10^{4}$ per $\mathrm{ml}$ were used and this would be expected to amplify such effects. It should be noted that stimulation of growth of brucellae by erythritol was inhibited in a synthetic medium by high concentrations of glutamate (Anderson and Smith) and was not observed on certain nutrient agar media studied by Keppie, Witt and Smith (1966). It is unlikely that a similar inhibition of erythritol enhancement of $V$. fetus occurred in all the media tested in the present study since the media differed considerably in nutrient composition.

Erythritol does not appear to be involved in the predilection of other pathogens for the placenta: Listeria monocytogenes, which apparently localises in the ovine placenta, was not stimulated by erythritol (Trivett and Meyer, 1967); Br. canis did not metabolise erythritol (Jones et al., 1968) although the organism localises in the canine placenta and causes pathological changes similar to those in ungulate brucellosis (L. E. Carmichael, cited by Jones et al.).

The high growth rate of $V$. fetus in foetal cotyledon extract, equalled only in maternal liver and kidney extracts, lends support to the hypothesis that a growth stimulant occurs in the ovine placenta. In studies with $\mathrm{Br}$. abortus, highest growth rates were also observed in foetal cotyledon and liver extracts (Williams et al., 1962; Williams, 1963). Since we found that the diffusible component of extracts was toxic in the present study, inhibitory factors that might have been released during the extraction procedure could have partially masked the effect of the stimulatory factors present. This possibility will be investigated in our further studies with the $V$. fetus model.

\section{SUMMARY}

The extent of placental localisation of Vibrio fetus after experimental infection of pregnant ewes has been examined and a nutritional basis for the localisation has been investigated. After infection, $V$. fetus was found only in 
the uterine contents; the placenta and chorion were most consistently infected. In advanced infection, quantitative measurement revealed that the placenta, allantoic fluid and chorion together contained 80-90 per cent. of the total organisms present.

Erythritol, the factor responsible for the localisation of Brucella spp. in the bovine and ovine placenta, failed to stimulate the growth of $V$. fetus in a range of media. The rate of growth of $V$. fetus in extracts of foetal cotyledon was greater than that observed when the organism was grown in extracts of most other tissues; this finding supports the hypothesis that the tissue predilection is dependent on local nutrients.

We are indebted to Dr D. J. MacKinnon for information on growth media and to Dr J. Keppie for help with animal experiments. The authors are members of an MRC Research Group on Mechanisms of Microbial Pathogenicity.

\section{REFERENCES}

ANDERSON, J. D., AND SMITh, H. . . . 1965. J. Gen. Microbiol., 38, 109.

Badger, E. H. M., ANd Pankhurst, 1960. J. Appl. Bact., 23, 28. EILEEN S.

Fletcher, R. D., ANd Plastridge, W. N. 1963. J. Bact., 85, 992.

Jensen, R., Miller, V. A., AND Molello, 1961. Amer. J. Vet. Res., 22, 169. J. A.

Jones, LoIs M., ZANARd, Marilyn, 1968. J. Bact., 95, 625. LEONG, D., AND WILSON, J. B.

KePPIE, J. . . . . . . . . . 1964. Symp. Soc. Gen. Microbiol., $14,44$.

KePPIE, J., Witt, K. A., ANd Smith, H.. 1966. J. Appl. Bact., 29, 556.

McFadyean, J., and Stockman, S. . . 1913. Rep. Dep. Comm. Bd. Agric. Fish.,

MATHER, K. Part III-Abortion in sheep, London.

Meynell, G. G., AND Meynell, Elinor 1965. Theory and practice in experimental

Miles, A. A., Misra, S. S., AND Irwin, 1938. J. Hyg., Camb., 38, 732. J. $O$.

Pearce, J. H., Williams, A. E., Harris- 1962. Br. J. Exp. Path., 43, 31. Smith, Patricia W., Fitzgeorge, R. B., AND SMITH, $H$.

Ringen, L., AND Frank, F. W. . . . 1963. J. Bact., 86, 344.

Ristic, M., White, F. H., AND Doty, 1958. Amer.J. Vet. Res., 19, 99. R. B.

SмIтH, H. . . . . . . . . . 1968. Bact. Rev., 32, 164.

Smith, H., Anderson, J. D., KepPIE, J., 1965. J. Gen. Microbiol., 38, 101. Kent, P. W., AND Timmis, G. M.

Smith, H., Keppie, J., Pearce, J. H., 1961. Br.J. Exp. Path., 42, 631. Fuller, R., ANd Williams, A. E.

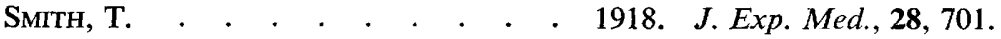

Trivett, T. L., AND Meyer, E. A. . . 1967. J. Bact., 93, 1197.

Williams, A. E. . . . . . . . . 1963. Ph.D. Thesis, Univ. London.

Williams, A. E., Keppie, J., ANd Smith, 1962. Br. J. Exp. Path., 43, 530. H. 